\title{
A PRODUÇÃo DE SENTIDO NA DIALÉTICA DA RECONSTRUÇÃo HISTÓRICA DO CONGADO EM UBERLÂNDIA
}

\author{
Gerson de Sousa \\ Faculdade de Educação, Universidade Federal da Uberlândia, Brasil \\ Clarice Bertoni \\ Faculdade de Educação, Universidade Federal da Uberlândia, Brasil
}

\begin{abstract}
Resumo
Será que a produção de sentido do presente do Congado, no cotidiano de Uberlândia, pode ser ratificado pela reconstrução histórica do passado da luta pela identidade do ser negro, sem que recaia na despolitização dos sujeitos pela beleza da representação folclórica ou de ser atrativo turístico? Esse é o problema que move este artigo para analisar historicamente, no campo da comunicação, a produção de sentido do Congado em Uberlândia. A morte de velhas personalidades e a necessidade de renovação deixou em aberto uma ruptura do presente para $\circ$ passado. É como se o fio da tradição estivesse se rompendo. As perguntas nos remetem a percorrer a análise cultural, por meio dos Estudos Culturais, em que a historicidade, a dialética e o sujeito em movimento se constituem como fatores primordiais para compreender a história do Congado em meio à complexidade dialética do percurso histórico.
\end{abstract}

\section{THE PRODUCTION OF MEANING IN THE DIALECTIC OF HISTORICAL RECONSTRUCTION OF “CONGADO” IN UBERLÂNDIA}

\begin{abstract}
Is it possible that the production of meaning of "Congado", in the daily life of the city of Uberlândia, can be ratified by the historical reconstruction of the past struggle for black identity, without the risk of depoliticization of the subjects by the beauty of the folkloric representation or by being a tourist attraction? This is the problem analyzed in this article, which aims at historically examining the production of meaning of "Congado" in the city of Uberlândia, MG, Brazil. The death of ancient personalities and the need for renewal have created a disruption between the present and the past. It is as if the threads of tradition were being broken. These questions lead us to undertake cultural analysis, through Cultural Studies, in which historicity, dialectic and the subjects in movement constitute primordial factors, to understand the history of Congado amid the dialectical complexity of its historical course.
\end{abstract}

\section{KEYWORDS}

Congado; daily life; Cultural Studies; dialectic; communication 


\section{INTRODUÇÃO}

Será que a produção de sentido do presente do Congado', no cotidiano de Uberlândia, pode ser ratificado pela reconstrução histórica do passado da luta pela identidade do ser negro sem que recaia na despolitização dos sujeitos pela beleza da representação folclórica ou de ser atrativo turístico? Esse é o problema que move este artigo que procura analisar historicamente, no campo da comunicação, a produção de sentido do Congado em Uberlândia. Este artigo é resultado das reflexões e desenvolvimento prático da pesquisa "A construção da identidade do popular no processo comunicativo: análise cultural da produção de sentido e representação do Congado no cotidiano de Uberlândia", que teve início em 2018, com o financiamento da FAPEMIG - Fundação de Amparo à Pesquisa do Estado de Minas Gerais.

Se por um lado temos de considerar o problema teórico de análise do Congado, em Uberlândia, por outro temos de considerar a dialética do cotidiano em que esses sujeitos estão inseridos. E o primeiro dilema está na própria concepção da experiência por meio da oralidade. A morte de velhas personalidades e a necessidade de renovação deixou em aberto uma ruptura do presente para o passado. É como se o fio da tradição estivesse se rompendo. As novas gerações que entram no Terno Congado Sainha ${ }^{2}$ não só desconhecem os sujeitos que lutaram no passado para manter essa manifestação, como potencializam para outras produções de sentidos a sua participação no Terno. Eis aqui um dilema discutido por Benjamin. A pergunta, que traduz a denúncia da pobreza da experiência, ainda ressoa e repercute no atual:

sabia-se exatamente o significado da experiência: ela sempre fora comunicada aos jovens. De forma concisa, com a autoridade da velhice, em provérbios; de forma prolixa, com a sua loquacidade, em histórias; muitas vezes como narrativas de países longínquos, diante da lareira, contadas a pais e netos. Que foi feito de tudo isso? Quem se encontra ainda com aqueles que sabem contar uma história? Quem ouve ainda as palavras dos antepassados que passam de uma geração para a seguinte como um anel precioso? Quem convoca um provérbio quando é preciso? E "quem tentará, sequer, lidar com a juventude invocando a sua experiência?" (Benjamin, 1986, p. 195)

Para mergulhar neste dilema torna-se necessário percorrer a reconstrução histórica do popular em Uberlândia. Para a luta que se efetiva da cultura popular e da história oral é sintomático compreender que se origina do próprio grupo a emergente solicitação de que se faça uma intervenção no presente. Mesmo que para isso se coloque em

\footnotetext{
" "Congada" ou "Congado" é uma manifestação cultural brasileira de influência africana e católica. Os grupos de Congado são compostos por uma série de atos rituais populares, que lhes permitem preservar a sua tradição. Mas, ao mesmo tempo, adotam uma postura dinâmica, que os mantém vivos ao longo do tempo. Entre religiosidade e profanação, Congado é uma festa com atrações encantadoras da etno-música (Gabarra, 2003).

${ }^{2}$ Ternos são os grupos que se unem através de uma cultura macro africana e compõe o congado. Cada terno tem como núcleo uma família consanguínea, que forma uma grande família. O terno pode ter até quatro capitães, sendo que o primeiro capitão representa o pai daquele grupo e o seu filho de sangue deve substituí-lo quando morrer (Gabarra, 2003).
} 
movimento dialético o próprio conceito de oralidade materializado na tradição. Há, em um primeiro momento, a identificação de valorizar o sujeito velho como experiência de vida. E ao mesmo tempo reconhecer que o percurso histórico do Congado em Uberlândia pode ser narrado por meio da história de vida. Neste contexto, o velho é sujeito do processo de ressignificação e sua experiência vivida se funda como elemento importante para desvelar o conceito de Congado.

Mas, por outro lado, a emergência nos revela que a força desta experiência do veIho está mergulhada no passado, o que configura uma distância não só geracional. $\mathrm{A}$ ausência da voz desses sujeitos velhos como orientação de sentido para as novas gerações indica que precisa ser contextualizada no movimento do presente. E aqui está o ponto da oralidade: a transmissão que seguiria na natureza social da organização dos ternos por meio do saber oral agora vem sendo solicitado para ser transposto no sistema de gravação de imagens deste velho. Longe de ser somente um procedimento de variação metodológica, é necessário problematizar essa mudança substantiva de fator, do oral para o vídeo, do método para teoria. Pois há algo incômodo em considerar que a velhice seja assistida pelos jovens para que se possa revelar como sujeito histórico e levar essa nova geração a compreender o mesmo sentido do presente por meio de outros dilemas e tensões do passado. De simples movimento de procedimento, o vídeo nos coloca diante do desafio: evitar que o meio definido para apreender a imagem do outro, do veIho congadeiro, não se estabeleça como fator determinista, com um fim em si mesmo, da leitura do jovem, no presente, sobre a cultura do Congado.

É este conceito de cultura que torna-se importante problematizar neste quadro social a partir da defesa teórica da centralidade da cultura, por Stuart Hall. O autor considera dois fatores para compreender cultura como fundante para compreender a realidade: o substantivo e o epistemológico:

por substantivo, entendemos o lugar da cultura na estrutura empírica real e na organização das atividades, instituições, e relações culturais na sociedade, em qualquer momento histórico particular. Por epistemológico, nos referimos à posição da cultura em relação às questões de conhecimento $\mathrm{e}$ conceitualização, em como a cultura é usada para transformar nossa compreensão, explicação e modelos teóricos do mundo. (Hall, 1997, p. 15)

O lugar da cultura na estrutura empírica real nos converge para compreender o cotidiano como produção de sentido para a construção da identidade do Terno Sainha no Congado. E aqui surge um primeiro indicativo dialético para a reflexão: o cotidiano como este estado de tensão e conflito, como nos dimensiona Certeau (1995), ou no enfrentamento da determinação em seu processo de construção de identidade, a partir de Hall (2003). Ao considerar o Congado como movimento de sujeitos na história, temos de considerar como natural a incorporação de outros elementos no decorrer do processo de identidade. E aqui é imprescindível discernir o sentido deste movimento. A incorporação de outros elementos valorativos na atualidade da cultura do Congado para expressar a produção de sentido no cotidiano pode ser dimensionada como ressignificação? Ou se 
trata de um desvio de significado que pode, de alguma forma, aprisionar o terno em uma presentificação na qual esvazia sua historicidade? A pergunta ora nos coloca na tradução da cultura como substantivo, ora nos desloca para a exigência de compreende-la pela concepção epistemológica.

A problemática inicial vinda do Terno está no distanciamento em que as temporalidades de velhos e jovens se tensionam no encontro no tempo presente. $E$ aqui advém a pergunta: não se corre o risco de o passado ser conduzido aqui como sem sentido ao presente? Com qual força os problemas demarcados do passado sobre a história do Congado podem reorientar a produção de sentido do presente destes jovens para construir outro valor? E como a experiência vivida do passado pode não ser conduzida aqui como violência da tradição ao outro da nova geração? As perguntas nos remetem a percorrer a análise cultural, por meio dos Estudos Culturais, em que a historicidade, a dialética e o sujeito em movimento se constituem como fatores primordiais para compreender a história do Congado em meio a complexidade dialética do percurso histórico.

Ao tratar do conceito de cultura, temos de esclarecer aqui que a interpretação analítica do Congado está fundamentada a partir do que se denomina processo comunicativo. É preciso entender a totalidade do que se denomina como processo comunicativo para compreender a leitura que se efetiva do Congado em Uberlândia. O primeiro aspecto é a crítica a uma abordagem positivista de comunicação em que coloca em situações descontextualizadas e fragmentadas o emissor em relação ao receptor. E, nesse contínuo, a crítica também se dispara para o conceito de comunicação como transmissão de informação. Esse delineamento nos coloca então em outro lugar de fala: da produção de sentido dos sujeitos que se expressam tanto como emissor quanto como receptor. Este último, a elaboração de sentido pode ser articulada pelo processo de consumo e circulação e interpretação da notícia. O que está em ênfase aqui é a recusa de qualquer determinismo tecnológico ou pressuposto comportamental de efeito que sinalize outras concepções teóricas como comunicação.

Há uma defesa explícita em Estudos Culturais de que a análise do cotidiano é realizada a partir do olhar do outro marginalizado no processo de formação da história. Se as teorias apresentam concepções a partir do massivo e do receptor enquanto objeto ou sujeito a ser conscientizado, partimos do pressuposto de que a identificação das táticas e estratégias do sujeito e seu efetivo processo de comunicação leva a retomar o caminho a partir do confronto com outras perspectivas da realidade. A defesa aqui é enquanto memória e passado como movimento histórico e do sujeito como defesa teórica.

O conceito de táticas e estratégias está encadeado na concepção de Michel de Certeau (1994):

as táticas são procedimentos que valem pela pertinência que dão ao tempo às circunstâncias que o instante preciso de uma intervenção transforma em situação favorável, à rapidez de movimentos que mudam a organização do espaço, às relações entre momentos sucessivos de um "golpe", aos cruzamentos possíveis de durações e ritmos heterogêneos. (Certeau, 1994, p. 102) 
E como contextualiza: assim, a tática é movimento dentro do campo de visão do inimigo e no espaço por ele controlado; "em suma a tática é a arte do fraco" (Certeau, 1994, p. 102).

O principal elemento aqui é compreender como a produção de sentido narrada pela história do Congado, a partir da articulação com as lutas do popular na história do Brasil, pode ser entendido como construção de identidade ou está redefinido pela representação incorporada da violência que o aflige. E aqui se instaura a diferença primordial para mergulharmos na proposta metodológica da análise cultural: trata-se de entender os dilemas da identidade a partir da tensão e conflito na experiência vivida do sujeito. $E$, por outro campo, de entender como a determinação das relações de poder sofrida pelos Ternos de Congado no decorrer da história se efetivam como violência, e como essa violência reorienta a construção dos sujeitos neste processo. O primeiro passo para esta primeira análise descritiva é entender, mesmo que em síntese, a trajetória do sentido do Congado em Uberlândia e como se pode estabelecer essa relação com o conceito de passado, traduzido aqui como memória.

\section{O CONGADO EM UBERLÂNDIA}

O Congado surge como uma dança de autoafirmação identitária e um instrumento de resistência social. Representa a coroação dos reis de Congo e Angola e as lutas entre reinos africanos. Incorporam o culto aos santos católicos padroeiros dos escravizados, como São Benedito, Nossa Senhora do Rosário, Santa Efigênia e São Elesbão, aos elementos da tradição africana. Está presente em vários estados do Brasil, com maior representatividade em Minas Gerais, São Paulo, Goiás e Paraná. É também caracterizado como Candombe, Moçambique e Congo (Munanga \& Nilma, 2004). A reunião de todos os Ternos é a Congada. "Entende-se como Terno de Congada os diferentes agrupamentos de congadeiros que comumente participam das festas de Congada por todo o Brasil. Estes podem se dividir entre diferentes tipos: Moçambiques, Congos, catopés, marinheiros, penachos, vilões, entre outros" (Macedo, citado em Carvalho, 2008, p. 3).

Os primeiros relatos do Congado registrados no município de Uberlândia datam de 1874, quando negros escravizados nas fazendas começaram a se reunir próximo ao local conhecido hoje como Posto da Matinha. De lá, o encontro passou para a Praça dos Bambus e depois para a Praça Dr. Duarte, onde ficou por alguns anos. Uma igreja chegou a ser construída, mas a área nas imediações era uma região elitizada, que abrigava fazendeiros e comerciantes. No intuito de distanciar os festejos do centro da cidade, os congadeiros foram deslocados para uma área periférica, atual Praça Rui Barbosa, em 1891. Uma capela foi estabelecida para que os negros pudessem fazer suas orações separados dos brancos. Ganhou a alcunha de Igreja do Rosário, assim como a festa em louvor à santa, comemorada em sete de outubro (Brasileiro, 2019).

Finalizada a obra, a capela foi entregue aos cuidados da Confraria do Perpétuo Socorro, pertencente à Paróquia Nossa Senhora do Carmo, formada por mulheres brancas do grupo social hegemônico. Em 1916, os negros devotos do Rosário de Maria 
organizaram e constituíram a Irmandade Nossa Senhora do Rosário dos Homens de Cor e a partir de então, tornaram-se responsáveis pela igreja. Esta mudança de mãos da chave "vai produzir uma ruptura institucional. As mulheres associadas à Confraria, passaram a realizar a festa da Virgem do Rosário em outubro, fazendo com que os negros ficassem com suas louvações no mês de novembro" (Brasileiro, 2019, p. 95). Além da mudança de data na comemoração da festa do Congado, a Irmandade passou a conviver com imposições de normas e regras determinados pela Diocese.

A cidade expandiu-se e em 1930, o prédio atual da Igreja do Rosário foi pensado e edificado com a colaboração da população local. A imprensa à época noticiava que esta construção, com arquitetura imponente, estava mais condizente e embelezaria a praça (Lopes, 2007). O farmacêutico Cícero Macedo de Oliveira, tendo construído sua residência nos fundos da capela, teve "a iniciativa de levantar no mesmo local uma nova igreja, mas com a sua frente voltada para o norte - sentido Avenida Floriano Peixoto, Afonso Pena" (Teixeira, 1970, p. 180). Brasileiro observa que:

se de um lado, Tito Teixeira informa que a construção da igreja foi resultante do apoio do povo de Uberlândia sempre solícito, que contribuiu com meios financeiros destinados à edificação da igreja através de profissionais liberais e comerciantes como Cícero Macedo, Abelardo Pena, Arlindo Teixeira e Manoel Alves; por outro lado, um testemunho de Manoel Rodrigues Siricoco, capitão do Moçambique de Belém, reforça por meio da oralidade a participação da comunidade do Congado na construção dessa segunda Igreja. (Brasileiro, 2019, p. 117)

"Cada pessoa que vinha da roça, trazia um carro de lenha do mato, chegava aqui, se ele vendia o carro de lenha por doze mil réis, dois mil réis ficavam pra construção da Igreja do Rosário" (Siricoco citado em Brasileiro, 2019, p. 117). Em 1940, ocorre a demolição da paróquia de Nossa Senhora do Carmo e as mulheres da Confraria do Perpétuo Socorro migram para a Catedral de Santa Terezinha. Porém, a festa em homenagem a Nossa Senhora do Rosário no mês de outubro continuou sendo realizada até a década de 1950, época em que surge uma terceira festa junto às comemorações da abolição da escravatura, realizada no mês de maio em louvor a São Benedito. Esta festa era protagonizada por negros congadeiros do bairro Martins e adjacências, que não participavam da Irmandade de Nossa Senhora do Rosário e criaram a Associação de São Benedito (Brasileiro, 2019).

"Havia uma igrejinha para São Benedito, coberta de palhas, num lugar mais distante do Martins, atual Rua Ângelo Testa, onde hoje é o Bairro Osvaldo Rezende" (Cassimiro citado em Brasileiro, 2012, p. 91). Entretanto, no final da década de 1960, a festa do mês de maio deixou de existir. Com isso, a Associação recém criada se desfez e seus ternos se juntaram a Irmandade Nossa Senhora do Rosário. A imagem de São Benedito que estava na capela do Martins foi levada em procissão até o Asilo São Vicente de Paulo. Após sua restauração, foi levada até a Igreja do Rosário para compor o altar junto a Nossa Senhora (Brasileiro, 2019). 
A década de 1970 trouxe alterações no Congado. É nesta época que a presença negra feminina ganha destaque ao desfilar pelas ruas. As mulheres sempre estiveram presentes, mas é a partir de então que elas se afirmam enquanto componentes ativas nas funções outrora exercidas só por homens. "De portadoras de bandeiras a carregadoras de estandartes, elas ocupam a estrutura de um grupo de Congado, sendo presidentes, capitãs, mães de santo e protetoras espirituais e, igualmente são percussionistas de vários instrumentos" (Brasileiro, 2019, p. 59). A partir de então, começam a aparecer mudanças de ritmos, de nomenclaturas e muitos grupos aderem a uma percussão característica das "paradinhas", realizadas pelas baterias das escolas de samba. Estas alterações ganham força na década de 1980 (Brasileiro, 2019). É também nessa década, mais precisamente em 1985, que a Igreja Nossa Senhora do Rosário foi tombada enquanto Patrimônio Cultural e Material do município de Uberlândia.

A partir da década de 1990, o bairro Patrimônio, um dos lugares ocupados por considerável população negra desde o século XVIII, passa a sofrer intervenções urbanísticas constantes em um processo de ascensão socioeconômica, culminando com a expulsão dos moradores antigos.

Por quase cinco décadas esteve situado no bairro Patrimônio, e, por circunstâncias diversas, como especulação imobiliária, morte de familiares e outras pressões sociais, teve com isso, o seu deslocamento para o bairro Campo Alegre, lugar residencial de seu principal responsável. Deslocar-se nesse sentido, significa reconstruir novas táticas de sobrevivência, de recriar novos vínculos de vizinhança, de continuar, mesmo em outro bairro distante, a manter sua tradição cultural e religiosa. (Brasileiro, 2019, p. 204)

No final dessa década, o número de grupos aumenta significativamente e junto a esse fenômeno há uma crescente presença de jovens, crianças e mulheres. Essa expansão do número de componentes faz com que alguns ternos cheguem até quinhentos integrantes. Em 2001 é criado o Moçambique Estrela Guia, do bairro São Jorge. O grupo surge com uma proposta de inserir adolescentes, adotar uma forma de dançar incorporada da cultura Hip Hop, aumentar o número de percussão e criar novos cânticos, vestuários e gingados. "Durante os rituais celebrativos em homenagem a Nossa Senhora do Rosário e São Benedito em frente da Igreja do Rosário, esses jovens dançadores receberam aplausos do público, mas incomodaram os moçambiqueiros tradicionalistas" (Brasileiro, 2012, p. 125).

Outro detalhe peculiar do terno é a figura do menino "Mameto" que aparece nos seus estandartes. No quintal do Moçambique Estrela Guia, a figura do menino está retratada entre as pinturas dos santos devocionais, Nossa Senhora do Rosário e São Benedito:

a figura do menino "Mameto", erguido por várias mãos, transformou-se em peça publicitária do grupo Moçambique Estrela Guia de Uberlândia, uma logomarca que transcende os dias de festa e se apresenta em cartazes, 
folders, banners, camisetas, caixinhas de fósforos e mini estandartes, distribuídos em apresentações culturais extemporâneas do grupo. Dessa forma, a imagem de "Mameto", no decorrer dos anos, transformou-se também em uma identidade visual do grupo. (Brasileiro, 2012, p. 124)

Em 2003, houve uma alternância no calendário da celebração do Congado, que voltou a acontecer no mês de outubro depois de quase nove décadas. Tal mudança foi defendida por Padre Olimar Rodrigues, responsável pela Igreja Nossa Senhora do Rosário, numa tentativa de unir a liturgia com a manifestação popular. Esta reaproximação vinculava novamente a festa com a devoção em data celebrada no calendário católico de São Benedito e Nossa Senhora do Rosário, cinco e sete de outubro respectivamente. No entanto, para muitos congadeiros, a mudança significava uma perda de tradição, pois suas memórias estavam forjadas com a festa da Congada no mês de novembro (Brasileiro, 2012).

Cinco anos depois, o Congado foi registrado como Patrimônio Imaterial Municipal pela prefeitura de Uberlândia. O Patrimônio Histórico e Cultural foi gravado no Livro das Celebrações por meio do Decreto número 11.321, de 29 de agosto de 2008. E através do Decreto número 17.903, de sete de janeiro de 2019, a Irmandade do Rosário conquistou, junto ao Conselho Municipal de Patrimônio Histórico, Arqueológico, Artístico e Cultural (COMPHAC), providências no sentido de reconhecer a Praça do Rosário como lugares de memória, resistência e permanência da comunidade negra congadeira no hipercentro da cidade de Uberlândia.

\section{MEMÓRIA E IDENTIDADE}

Em seu estudo sobre "Memória e Identidade Social", Michael Pollak (1992) argumenta que, a princípio, a memória parece ser um fenômeno individual, íntimo e próprio da pessoa. Mas o próprio sociólogo retoma Halbwachs e esclarece que a memória deve ser entendida, sobretudo, como um fenômeno coletivo ou social. A memória do sujeito existe a partir de uma memória coletiva e as lembranças são constituídas no espaço do grupo. Assim, elas podem se reorganizar de acordo com a percepção de outros sujeitos e da representação da memória histórica. Halbwachs (1968) trata a memória coletiva como um processo de reorganização do passado vivido por determinado grupo social, permitindo a compreensão de que a rememoração não depende apenas do que o indivíduo lembra, mas também de fragmentos da memória do grupo à qual pertence.

Pollak (1992) precisa três elementos que constituem a memória, individual ou coletiva: em primeiro lugar estão os acontecimentos vividos pessoalmente; em segundo lugar, são os acontecimentos que o autor denomina como "vividos por tabela", aqueles dos quais a pessoa não participou diretamente, mas que foram vividos pela coletividade à qual ela pertence; e, em terceiro, as pessoas, personagens e lugares ligados a uma lembrança que pode ser pessoal ou "herdada" da comunidade. A memória dos moradores de Uberlândia situa-se nesse campo em que se cruzam os modos de ser do sujeito e o mundo social; as instituições e os diferentes atores e grupos, cujos 
conflitos sociais fazem parte de suas trajetórias. Esse fator coloca como exigência metodológica que se produza na análise da contemporaneidade a articulação dos dilemas do presente com o processo histórico no qual a narrativa estará amparada.

O autor ressalta que as datas marcadas no calendário de um município são fortemente estruturadas do ponto de vista político. Quando se procura enquadrar a memória de uma região por meio de datas oficialmente selecionadas para as festas municipais, cria-se um lugar de luta política. A memória oficial constitui um objeto de disputa importante, e são comuns os conflitos para determinar quais dias e quais acontecimentos vão ser gravados na memória de um povo (Pollak, 1992). Assim, em Uberlândia, definiu-se duas festas distintas em homenagem a Nossa Senhora do Rosário: a da Confraria no mês de outubro e a da Irmandade no segundo domingo do mês de novembro. Mesmo após a migração das mulheres da Confraria para a Catedral de Santa Terezinha, elas continuaram realizando a festa em homenagem à Nossa Senhora do Rosário em outubro (Brasileiro, 2019).

Tal conflito se repete décadas depois, em 2003, quando a Diocese e a Irmandade retorna a data das celebrações do Congado para outubro, gerando a insatisfação dos congadeiros. Pollak explica que "as preocupações do momento constituem um elemento de estruturação da memória" (Pollak, 1992, p. 4). A organização em função das preocupações pessoais e políticas do presente mostra que a memória é um fenômeno construído e o resultado de um trabalho de organização. É importante ressaltar que essa mudança acontece numa época em que o Congado conquistou muitos adeptos e que seus Ternos cresceram em número e componentes. Algo que pode ser explicado pela relação entre a memória da escravidão e a valorização do Congado no tempo presente:

podem existir acontecimentos regionais que traumatizaram tanto, marcaram tanto uma região ou um grupo, que sua memória pode ser transmitida ao longo dos séculos com altíssimo grau de identificação. Locais muito longínquos, fora do espaço-tempo da vida de uma pessoa, podem constituir lugar importante para a memória do grupo, e por conseguinte da própria pessoa, seja por tabela, seja por pertencimento a esse grupo. A memória da África, pode fazer parte da herança da família com tanta força que se transforma praticamente em sentimento de pertencimento. (Pollak, 1992, p. 5)

O Congado passou por um processo de transformação, tornando-se um patrimônio cultural herdado e reconstruído em que os sujeitos reafirmam sua identidade, ganham visibilidade, ratificam politicamente suas trajetórias históricas e o pertencimento no cotidiano da cidade. Dessa forma, novas perspectivas surgem no grupo, mantendo vivas as histórias da ancestralidade, para que as lembranças permaneçam no presente (Brasileiro, 2019). O passado é uma área de conflito e a este se referem, quase sempre em concorrência, a memória e a história. Em Uberlândia, as memórias foram construídas e reconstruídas ao longo do século $X X$, mas sempre pertenceram a uma memória coletiva que se iniciou no processo pós-abolicionista e que não ouviu todas as vozes durante o processo histórico. 
A memória dos congadeiros é marcada pela construção social. Diante do quadro de modernização da sociedade, esses sujeitos enfrentaram a questão da urbanização que, por sua vez, trouxe consigo elementos transformadores na configuração do processo cultural dos povos de comunidades rurais, pressões sociais e imobiliárias, além do racismo legitimado na delimitação de lugares diferentes para brancos e negros (Lopes, 2007). Trata-se de vivências e narrativas de uma experiência que a história oficial deixou de contar. As interpretações do passado que se quer salvaguardar, se integram em tentativas de definir e reforçar sentimentos de pertencimento entre coletividades: região, partidos, famílias, etc. A referência ao passado serve para manter a coesão dos grupos e das instituições que compõem uma sociedade, para definir seu lugar respectivo, mas também as oposições irredutíveis (Pollak, 1989).

A separação das festas no século passado, evidencia a segregação racial que persistia no cotidiano da cidade. E essa divisão não se restringia aos lugares de oração. Durante muitas décadas, além de não rezarem juntos, brancos e negros não frequentavam os mesmos espaços em cinemas e clubes, além de andarem em calçadas diferentes (Sousa, 2014). Esta dinâmica racista é diretamente responsável pela forma como a história do município de Uberlândia foi sendo construída por um grupo que procura legitimar os acontecimentos através de um trabalho que Pollak chama de enquadramento da memória, que pode ser feito em organizações políticas, sindicais, na igreja e em tudo aquilo que leva os grupos a solidificarem o social (Pollak, 1992).

As memórias coletivas criadas e defendidas por um trabalho de enquadramento são importantes para a continuidade do tecido social e das estruturas institucionais de uma sociedade. Não se trata de uma falsificação do passado, mas de sua reorganização conforme a necessidade daquele grupo de manter a sua coesão. "A análise do trabalho de enquadramento de seus agentes e seus traços materiais é uma chave para estudar, de cima para baixo, como as memórias coletivas são construídas, desconstruídas e reconstruídas" (Pollak, 1992, p. 10). É colocada uma realidade que legitima a história de grupos específicos, compondo uma memória coletiva organizada, que resume a imagem que uma sociedade majoritária deseja passar e impor. Portanto, faz-se necessário buscar novas possibilidades a partir de outras vozes, fontes e documentos, para que possamos compreender as realidades que não compuseram as memórias coletivas de Uberlândia.

A partir da segunda metade do século XX, especificamente na década de 1970, teorias tentaram dar conta das novas formas de mobilização social existentes, fazendo com que as Ciências Sociais se voltassem para o estudo desses movimentos (Sousa, 2014). O sujeito voltou a ser preocupação dos pesquisadores e pôde-se compreender que as subjetividades eram iminentes e que a análise dessas relações entre pessoas e grupos seria fértil para as novas metas dos historiadores. "A sociologia da década de oitenta foi dominada pela temática dos novos sujeitos sociais e dos novos movimentos sociais (NMSs)" (Sousa Santos, 1999, p. 221). A importância política desses movimentos sociais cresceu significativamente no Brasil durante este período, que foram aos poucos conquistando espaço nas lutas de formulação de políticas, ganhando expressão e legitimidade no campo das preocupações sociais. 
É neste período que toma força a história oral, junto as novas concepções historiográficas. Ligava-se à nova linha de estudos culturais, levando em conta novos objetos, metodologias e fontes. Pollak (1992) explana que a história oral, a coleta de representações por meio da história oral, que é também história de vida, tornou-se claramente um instrumento privilegiado para abrir novos campos de pesquisa. A história tal como a pesquisamos pode ser extremamente rica como produtora de novos temas, de novos objetos e de novas interpretações. Por meio dela, é possível ouvir as memórias contadas por sujeitos que pertencem a grupos minoritários, que não compuseram o processo de construção das memórias oficiais de Uberlândia:

ao privilegiar a análise dos excluídos, dos marginalizados e das minorias, a história oral ressaltou a importância de memórias subterrâneas que, como parte integrante das culturas minoritárias e dominadas, se opõem à Memória oficial. Num primeiro momento essa abordagem faz da empatia com os grupos dominados uma regra metodológica e reabilita a periferia e a marginalidade. (Pollak, 1989, p. 2)

O conceito de "memória subterrânea" ou marginalizada, como propõe Pollak, refere-se à memória dos integrantes dos grupos dominados que não foram ouvidos e que se opõem à "memória oficial", criada para definir de forma universal a identidade da cidade. Trabalhar com as memórias coletivas subterrâneas é privilegiar os excluídos, oferecendo um novo ponto de vista da história e dos fatos sociais do passado, cuja referência "serve para manter a coesão dos grupos e das instituições que compõem uma sociedade, para definir seu lugar respectivo, sua complementaridade, mas também as oposições irredutíveis" (Pollak, 1989, p. 9). Perceber as mudanças e as continuidades nas práticas do Congado só é possível com a análise dos relatos, das experiências sociais e das memórias dos sujeitos, pois apesar de silenciada pela memória oficial ao longo dos anos, ela foi refeita de uma geração a outra oralmente e permanece viva.

\section{DeLimitação histórica}

Será que a produção de sentido do presente do Congado, no cotidiano de Uberlândia, pode ser ratificado pela reconstrução histórica do passado da luta pela identidade do ser negro sem que recaia na despolitização dos sujeitos pela beleza da representação folclórica ou de ser atrativo turístico? O problema aqui recuperado toma lugar diferente quando se toma consciência de que a narrativa do negro, do congadeiro, é fundante para se apresentar outra produção de sentido na história. Mais do que memória, se efetiva nesta leitura do passado a compreensão sobre a identidade desses homens e mulheres que vivenciam suas tensões e conflitos.

Para materializar esse empreendimento analítico se tomará por referência de temporalidade três períodos históricos, que consideramos importante para entender, mesmo delimitado, o movimento da cultura popular neste processo comunicativo. $O$ primeiro período se compreende no início do Congado, em 1874. E aqui se efetiva uma 
pergunta primordial: qual o sentido de efetivar uma crítica ao presente do século XXI de fato histórico ocorrido no final do século XIX? Poderíamos apresentar aqui, primeiro, que se trata de ser coerente com a abordagem metodológica da análise cultural. Por estar constitutiva do método dialético, a história se fundamenta como problema substantivo para a análise cultural, o que afasta a possibilidade de tratar a história aqui como periodização, como se fosse constituída por espaços ocupados por datas.

Ao tratar a história como problema analítico somos levados a considerar que a história do terno de Congado em Uberlândia está relacionada também ao contexto histórico em que a luta do negro se efetiva. E, por que não, considerar que o debate sobre a escravidão no país, cuja Lei Áurea foi assinada em 13 de maio de 1888, é o quadro analítico. Em sua obra, Alfredo Bosi (1992) apresenta o contexto da dialética da colonização. Em um dos trechos em que aborda a reforma e abolição, o autor mostra os embates ocorridos no Brasil no período de 1868 e que culminaria até 1888 . Bosi cita como elemento de análise, a distinção feita por Joaquim Nabuco sobre as cinco forças e os agentes que levaram da reforma para a abolição:

1) os abolicionistas que fizeram a campanha no Parlamento, na imprensa e nos meios acadêmicos; 2) os militantes da causa, abertamente empenhados em ajudar as fugas em massa e instruir os processos de alforria; 3 ) os proprietários de escravos, sobretudo nordestinos e gaúchos, que se puseram a libertá-los em grande número nos últimos anos do movimento; 4) os homens públicos (Nabuco os chama generosamente estadistas) mais ligados ao governo, que a partir da Fala do Trono de 1867, mostrou sua intenção de resolver gradualmente a questão servil; 5) a ação pessoal do imperador e da princesa regente. (Bosi, 1992, pp. 244-245)

É certo que o texto aqui enfatiza a dialética da colonização, mas o desfecho da carta de Nabuco depois do fechamento da problematização da república no Brasil sobre a questão dos negros a partir da narrativa do liberalismo é sintomático.

Nabuco escreve a Rebouças, que se auto exilaria para a África no dia mesmo da proclamação da República: Com que gente andamos metidos! Hoje estou convencido de que não havia uma parcela de amor do escravo, de desinteresse e de abnegação em três quartas partes dos que se diziam abolicionistas. Foi uma especulação mais! A prova é que fizeram esta República e depois dela só advogam a causa dos bolsistas, dos ladrões da finança, piorando infinitamente a condição dos pobres. É certo que os negros estão morrendo e pelo alcoolismo se degradando ainda mais do que quando escravos, porque são hoje livres, isto é, responsáveis, e antes eram puras máquinas, cuja sorte Deus tinha posto em outras mãos (se Deus consentiu na escravidão); mas onde estariam os propagandistas da nova cruzada? Desta vez nenhum seria sequer acreditado (...) Estávamos metidos com financeiros, e não com puritanos, com flâmulos de banqueiros falidos, 
mercenários de agiotas etc.; tínhamos de tudo, menos sinceridade e amor pelo oprimido. A transformação do abolicionismo em republicanismo bolsista é tão vergonhosa pelo menos como a do escravagismo". (Bosi, 1992, pp. 244-245)

A narrativa acima descrita permite entender o principal dilema pela dialética da colonização: o que aconteceu pós-lei áurea é que os negros escravizados foram atirados à própria sorte. E a pergunta que se coloca, como o próprio Bosi retrata os dilemas apresentados por Lima Barreto e Cruz e Souza sobre os negros, é como esse processo abolicionista e republicano traz para o presente daquele período outro dilema existencial para a modernidade. A construção crítica do olhar de Lima Barreto é encadeado por Bosi diante deste dilema dialético:

depois do treze de Maio, qual poderia ser a expectativa de negros e mulatos agregados, subproletários ou marginais? Já não se sustentava historicamente o mito da redenção de um povo inteiro. Só se concebem esperanças de resgate coletivo quando se vive, ou se crê viver, um tempo grávido de promessas: é a espera messiânica de um dia que virá para tudo julgar, libertar, salvar. Mas sobrevindo este Dia D, é o presente que se impõe com o fardo das suas contradições. Lima Barreto olhou na cara este seu presente, que foi a nossa República Velha. Como um observador que se sabe vencido mas não submisso à máquina social. (Bosi, 1992, pp. 266-267)

Sabe-se vencido mas não submisso à máquina social. Esse embate nos coloca diante dos conflitos sobre a realidade do negro no Brasil. E, como revelado anteriormente, pode ser estendido como contextualização da situação vivenciada pelos negros em Uberlândia neste período, como início do Congado em 1874. Há uma demarcação importante considerada por Bosi e que nos coloca diante da crise da modernidade. É quando os negros reconhecem que o Dia D tem outro sentido para o seu cotidiano. $O$ enfrentamento da falta de oportunidades econômicas e de ação social e a mentalidade escravagista que, no período pós-abolição, se efetiva e demarca nas micro relações sociais. O enfrentamento não é mais contra o estado escravagista, mas no interior das relações sociais.

É com este teor problemático que devemos lançar a análise para a história do movimento dos negros em sua produção de sentido sobre o Congado, em Uberlândia. Pois o período se configura como momento de tensão, de esperança e de um presente cujo resultado é a tomada de consciência de que o presente pós-abolição tem de ser enfrentado, para que o mesmo seja tratado como sujeito. E o primeiro sentido da luta, que se efetiva anos depois, é revelar que os passos para abolição passam pela a dialética dos colonizados como sujeitos. As rebeliões nas fazendas, as fugas em massa, a formação da sociabilidade dos negros em quilombos, a vida e a morte do líder Zumbi dos Palmares, produz a narrativa de que o negro atuou como sujeito na história do Brasil.

Por um lado podemos considerar a acusação de Lima Barreto sobre o ocorrido nesta Nova República: "no fundo, o que se deu em 15 de novembro foi a queda do 
Partido Liberal e a subida do conservador, sobretudo da parte mais retrógrada dele, os escravocratas de quatro costados" (Bosi, 1992, p. 267). Por outro, há essa narrativa do negro como sujeito questionador do processo escravocrata no Brasil, cuja ação definiu esse ser sujeito. Diante deste quadro como podemos considerar o início do movimento do Congado em Uberlândia, mesmo antes da constituição da própria cidade como município? Que concepção de coletivo de ser negro atravessa esse período até a revelação do presente do Dia D e seu resultado nas mudanças de significado? Ou melhor: quais foram as táticas e as estratégias utilizadas diante deste novo contexto que se apresenta a esse grupo?

O que se concebe é que essa forma de agir consciente de que sua existência tem sentido para além daquilo que o nega pode ser entendida como primeiro aspecto do movimento negro tal como a Frente Negra Brasileira, em 1931. Mas é no contexto de ordem internacional, principalmente com a luta disseminada também nos Estados Unidos, que florescem no Brasil novas frentes para lutar contra o racismo, as desigualdades e para exigir políticas públicas sobre os direitos dos negros. Esse período está sendo considerado como o segundo problema de delimitação histórica para analisar essa nova ressignificação dos ternos de Congado em Uberlândia. Entre os movimentos podemos citar o Movimento Negro Unificado. É inegável que os anos da década de 70 e 80 configuram, na historiografia, a crise da modernidade que se acentua desde o "desencantamento" do negro do pressuposto discurso de igualdade do Dia D.

É neste momento que as questões sobre o ser negro (black is beautiful) passam a tomar nova camada de crítica no corpo na sociedade brasileira para denunciar o racismo. É um período em que podemos analisar a luta por outros movimentos sociais como o das mulheres e a discussão sobre a velhice, para enquadrarmos o cotidiano do Terno de Congado de Uberlândia. A proposta a partir deste período é efetivar para a sociedade brasileira o sentido de identidade desses grupos e, ao mesmo tempo, revelar a obscuridade em que a narrativa do passado se efetivou no país. E é assim que os Ternos de Congado passam a ter novas leituras dos sujeitos que os compõem, tanto da luta do negro, quanto da mulher negra, quanto dos velhos. Aqui está o paradoxo: a produção de sentido deve contestar em sua constituição de identidade os valores que movem o preconceito.

Esse contínuo histórico do movimento negro toma novas dimensões no século XXI. A marcha Zumbi, em 1995, reuniu 30 mil pessoas, em Brasília, para exigir a inclusão e efetivação de políticas públicas aos negros. Mas ao mesmo tempo o reconhecimento dos Ternos se efetiva como novo problema. Do ponto de vista interno, houve o reconhecimento dessa ressignificação de ternos como o Estrela Guia. De outro, a luta para que a suposta aceitação como movimento de Uberlândia se dilua na aceitação de ser uma festa realizada em um dia, efetivando uma tradição folclórica. A luta é que se compreenda a cultura do Congado como política. Esse terceiro período de delimitação histórica, do século $X X I$, embora pareça próximo dos anos 60 , efetiva uma nova compreensão sobre o debate em comunicação, da qual efetivamos a crítica ao positivismo. Assim surge o temor de que o Congado seja mais tratado como fenômeno em si, sem que se valorize os 
sujeitos que produzem sentido no cotidiano de Uberlândia. Nesta lógica de negação, os congadeiros se defrontam com um novo modo de enfrentamento contra o preconceito.

\section{CONSIDERAÇÕES FINAIS}

A cultura popular existe em outro lugar que não no ato que a suprime? Este é o problema epistemológico lançado por Certeau (1995) no texto da "Beleza do Morto". A crítica em que se fundamenta o autor está na violência física seguida da violência simbólica com que a cultura popular é assolada na sociedade. Na narrativa que se efetiva do popular, embora seja preponderante a denúncia, mais se apresenta pela sua negativa do que pelo movimento afirmativo. Deste modo, o popular torna-se belo no momento em que sua força de mudança política por meio dos seus sujeitos é dilacerado pela violência do outro.

A análise da história dos Ternos do Congado, em Uberlândia, traz como preocupação essa problemática de contar mais a narrativa da violência sofrida pelos negros, em Uberlândia, do que o movimento que o constitui como identidade. A memória coletiva do sujeito da cultura popular perpassa pelas violências física e simbólica. Entretanto, seria errôneo considerar, por essa concepção teórica, que o sujeito negro do Terno de Congado se resume de forma restrita ao outro que o nega. E é no mergulhar da profundeza da experiência vivida do eu, por meio da memória, que a reconstrução histórica toma novo sentido em relação à historiografia oficial. E assim atingimos a memória em conflito, que na realidade se efetiva como a produção de sentido de sujeitos na disputa hegemônica da realidade brasileira.

A partir violência física do período em que se instaura a escravidão e da violência simbólica do presente em que a valorização da festa decreta o esvaziamento do sujeito, a crítica deve ser buscada agora na dialética do movimento negro, ou na dialética da construção de identidade do Congado. Os velhos que serão entrevistados estão demarcados neste contexto de luta, tanto do ser negro, quanto do ser velho, diante de uma determinação econômica capitalista. As novas gerações que se lançam para outras referências do movimento negro, como o Hip Hop, para produzir o sentido no cotidiano do Terno Congado, revelam as camadas com que as táticas e as estratégias vão tomando corpo para o significado social do próprio movimento.

O desafio teórico analítico, diante do dilema da historicidade apresentada do Congado, em Uberlândia, é desvelar a memória do outro, do marginalizado, a partir deste outro lugar de fala, que altera a compreensão da realidade social. Não se trata de recusar a violência sofrida pelo outro como problema de análise. Trata-se aqui de considerar que o eu, ao se reconhecer neste processo, produz novos sentido da história. E a narrativa dessas experiências, assim como os lugares de memória, são elementos essenciais para que a memória subterrânea permita que o não dito assuma uma nova configuração de ser, do sujeito que narra. A existência do sujeito negro torna-se o ponto central do discurso. A reescrita do passado por meio da memória do presente é o movimento do sujeito na constituição histórica de si e do grupo ao qual possui pertencimento. Torna-se, 
assim, possível reconfigurar, nesta nova leitura, a determinação das relações de poder que esses homens e mulheres negros conduzem e/ou são conduzidos a enfrentar na tensão do cotidiano.

\section{REFERÊNCIAS}

Benjamin, W. (1984). Reflexões: a criança, o brinquedo, a educação. São Paulo: Summus.

Benjamin, W. (1986). Documentos de cultura, documentos de barbárie: escritos escolhidos. São Paulo: Cultrix.

Bosi, A. (1992). Dialética da colonização. São Paulo: Cia das Letras.

Brasileiro, J. (2012). O ressoar dos tambores do Congado - entre a tradição e a contemporaneidade: cotidiano, memórias, disputas (1955-2011). Dissertação de Mestrado em História, Universidade Federal de Uberlândia, Uberlândia.

Brasileiro, J. (2019). O Congado (a) e a permanência do racismo na cidade de Uberlândia- MG: resistência negra, identidades, memórias, vivências (1978-2018). Tese de Doutorado em História, Universidade Federal de Uberlândia, Uberlândia.

Carvalho, E. F. (2008). O rosário de Aninha[manuscrito]: os sentidos dadevoção rosarina na escritura de Anna Joaquina Marques.Goiás: E. F. Carvalho.

Certeau, M. de. (1994). A invenção do cotidiano: artes de fazer. Petrópolis (RJ): Vozes.

Certeau, M. de (1995). A cultura no plural. Campinas (SP): Papirus.

Gabarra, L. O. (2003). Congado: a festa do batuque. Caderno Virtual de Turismo, 3(2). Retirado de http://www. ivt.coppe.ufr.br/caderno/index.php/caderno/article/view/32/30

Halbwachs, M. (1968). A memória coletiva. São Paulo: Ed. Vértice.

Hall, S. (1997). A centralidade da cultura: notas sobre as revoluções culturais do nosso tempo. Educação a Realidade, 22(2), 15-46.

Hall, S. (2003). Da diáspora: identidades e mediações culturais. Belo Horizonte: Editora UFMG.

Lopes, V. M. Q. C. (2007). Uberlândia: racionalidade urbana, religiosidade e tradições culturais. In M. C. Abdala \& M. C. T. Machado (Eds.), Caleidoscópio de saberes e práticas populares, catálogo da produção cultural do Triângulo Mineiro e Alto Paranaíba (pp. 76-77). Uberlândia: EDUFU.

Munanga, K. \& Gomes, N. L. (2004). Para entender o negro no Brasil de hoje: história, realidades, problemas e caminhos. São Paulo: Global; Ação Educativa.

Pollak, M. (1989). Memória, esquecimento e silêncio. Estudos Históricos, 2(3), 3-15.

Pollak, M. (1992). Memória e identidade social. Estudos Históricos, 5(10), 200-215.

Sousa Santos, B. (1999, abril). Os novos caminhos da teoria crítica. Conferência de encerramento do colóquio comemorativo dos 20 anos da Revista Crítica de Ciências Sociais: Sociedade, Cultura e Política no Fim do Século; a Reinvenção da Teoria Crítica. Coimbra.

Sousa, G. (2014). Memórias do cinema em Uberlândia pela análise da comunicação e cultura. Uberlândia: Universidade Federal de Uberlândia. 
Teixeira, T. (1970). Bandeirantes e pioneiros do Brasil central: história da criação do município de Uberlândia. Uberlândia: Uberlândia Gráfica LTDA.

\section{NOTAS BIOGRÁFICAS}

Gerson de Sousa é Professor do Curso de Jornalismo da Faculdade de Educação (FACED) da Universidade Federal de Uberlândia (UFU) e Professor Permanente do Programa de Pós-Graduação em Tecnologias, Comunicação e Educação (PPCCE), FACED UFU, Brasil. É Graduado em Jornalismo na UNIMEP, com Mestrado e Doutorado em Ciências da Comunicação pela Escola de Comunicações e Artes (ECA) da Universidade de São Paulo (USP). Pesquisador atuante nas áreas de Comunicação, cultura, memória e velhice com ênfase na linha teórica dos Estudos Culturais

ORCID: https://orcid.org/0000-0003-3857-3237

Email: gerson.sousa1971@gmail.com; gerson.sousa@ufu.br

Endereço: Faculdade de Educação, Avenida João Naves de Ávila, 2121, Campus Santa Mônica, Sala 1G156, CEP 38.408-100, Uberlândia (MG), Brasil

Clarice Bertoni é graduada em Jornalismo pela Universidade Federal de Uberlândia (UFU), Brasil, bacharel em Cinema e com MBA em Comunicação e Semiótica pela Universidade Estácio de Sá. Realiza pesquisa na área de Comunicação, cultura, velhice, experiência e memória.

ORCID: https://orcid.org/0000-0002-6385-309X

Email: clabertoni@hotmail.com

Endereço: Faculdade de Educação, Avenida João Naves de Ávila, 2121, Campus Santa Mônica, Sala 1G156, CEP 38.408-100, Uberlândia (MG), Brasil

Submetido: 14.05.2019

Aceite: 12.10.2019 